\title{
Increase of invasive meningococcal serogroup W disease in Europe, 2013 to 2017
}

Manuel Krone¹, Steve Gray², Raquel Abad³, Anna Skoczyńska ${ }^{4}$, Paola Stefanelli5, Arie van der Ende ${ }^{6}$, Georgina Tzanakaki, Paula Mölling ${ }^{8}$, Maria João Simões 9 , Pavla Kř́žzová ${ }^{10}$, Stéphane Emonet ${ }^{11}$, Dominique A. Caugant ${ }^{12}$, Maija Toropainen ${ }^{13}$, Julio Vazquez ${ }^{3}$, Izabela Waśk04, Mirjam J. Knol ${ }^{14}$, Susanne Jacobsson ${ }^{8}$, Célia Rodrigues Bettencourt ${ }^{9}$, Martin Musilek ${ }^{10}$, Rita Born ${ }^{15}$, Ulrich Vogel ${ }^{1}$, Ray Borrow ${ }^{2}$

1. Institute for Hygiene and Microbiology, University of Würzburg, Würzburg, Germany

2. Meningococcal Reference Unit, Public Health England, Manchester, United Kingdom

3. Spanish Reference Laboratory for Meningococci, National Centre for Microbiology, Instituto de Salud Carlos III, Madrid, Spain

4. National Reference Centre for Bacterial Meningitis, National Medicines Institute, Warsaw, Poland

5. Dept. of Infectious Diseases, Istituto Superiore di Sanità, Rome, Italy

6. The Netherlands Reference Laboratory for Bacterial Meningitis, Department of Medical Microbiology, Academic Medical Center, Amsterdam, Netherlands

7. National Meningitis Reference Laboratory, National School of Public Health, Athens, Greece

8. National Reference Laboratory for Neisseria meningitidis, Department of Laboratory Medicine, Faculty of Medicine and Health, Örebro University, Örebro, Sweden

9. Department of Infectious Diseases, National Institute of Health Dr. Ricardo Jorge, Lisboa, Portugal

10. National Reference Laboratory for Meningococcal Infections, National Institute of Public Health, Prague, Czech Republic

11. Division of Infectious Diseases, Geneva University Hospitals, Geneva, Switzerland

12. Division for Infection Control and Environmental Health, Norwegian Institute of Public Health, Oslo, Norway

13. Department of Health Security, National Institute for Health and Welfare (THL), Helsinki, Finland

14. Department of Epidemiology and Surveillance, National Institute for Public Health and the Environment, Bilthoven, the Netherlands

15. Division of Communicable Diseases, Federal Office of Public Health (FOPH), Bern, Switzerland

Correspondence: Manuel Krone (manuel.krone@uni-wuerzburg.de)

Citation style for this article:

Krone Manuel, Gray Steve, Abad Raquel, Skoczyńska Anna, Stefanelli Paola, van der Ende Arie, Tzanakaki Georgina, Mölling Paula, João Simões Maria, Křížová Pavla, Emonet Stéphane, Caugant Dominique A., Toropainen Maija, Vazquez Julio, Waśko Izabela, Knol Mirjam J., Jacobsson Susanne, Rodrigues Bettencourt Célia, Musilek Martin, Born Rita, Vogel Ulrich, Borrow Ray. Increase of invasive meningococcal serogroup W disease in Europe, 2013 to 2017. Euro Surveill. 2019;24(14): $\mathrm{pii}=1800245$. https://doi.org/10.2807/1560-7917.ES.2019.24.14.1800245

Background: The total incidence of invasive meningococcal disease (IMD) in Europe has been declining in recent years; however, a rising incidence due to serogroup W (MenW), predominantly sequence type 11 (ST-11), clonal complex 11 (cc11), was reported in some European countries. Aim: The aim of this study was to compile the most recent laboratory surveillance data on MenW IMD from several European countries to assess recent trends in Europe. Methods: In this observational, retrospective study, IMD surveillance data collected from 2013-17 by national reference laboratories and surveillance units from 13 European countries were analysed using descriptive statistics. Results: The overall incidence of IMD has been stable during the study period. Incidence of MenW IMD per 100,000 population (2013: 0.03; 2014: 0.05; 2015: 0.08; 2016: $0.11 ; 2017: 0.11$ ) and the proportion of this serogroup among all invasive cases (2013: 5\% (116/2,216); 2014: $9 \%(161 / 1,761)$; 2015: 13\% (271/2,074); 2016: $17 \%$ (388/2,222); 2017: 19\% (393/2,112)) continuously increased. The most affected countries were England, the Netherlands, Switzerland and Sweden. MenW was more frequent in older age groups ( $\geq 45$ years), while the proportion in children ( $<15$ years) was lower than in other age groups. Of the culture-confirmed MenW IMD cases, $80 \%(615 / 767)$ were caused by hypervirulent cc11. Conclusion: During the years 2013-17, an increase in MenW IMD, mainly caused by MenW cc11, was observed in the majority of European countries. Given the unpredictable nature of meningococcal spread and the epidemiological potential of cc11, European countries may consider preventive strategies adapted to their contexts.

\section{Introduction}

The total incidence of invasive meningococcal disease (IMD) in Europe has been declining in recent years; however, a rising incidence of IMD caused by serogroup W (MenW) was reported in the United Kingdom (UK) in 2009 [1], then the Netherlands [2] and Sweden [3], following the spread of MenW IMD in South America since 2004 [4]. The isolated strains predominantly belong to the multilocus sequence typing (MLST) defined hypervirulent clonal complex 11 (cc11).

Some patients with MenW:cc11 infection have been reported to present with gastrointestinal symptoms, which is uncommon for patients with IMD caused by meningococci of other serogroups [5]. The case fatality rate (CFR) of MenW IMD was described to be more than twice that of IMD caused by other serogroups, and the 
Number of invasive meningococcal disease cases and number and incidence of laboratory-confirmed MenW cases, by country, 13 EMGM-member countries, 2013-2017 ( $\mathrm{n}=10,385$ cases)

\begin{tabular}{|c|c|c|c|c|c|c|c|c|c|c|c|c|c|c|c|c|c|}
\hline \multirow{2}{*}{ Country } & \multicolumn{5}{|c|}{ Number of reported IMD cases } & \multicolumn{5}{|c|}{ MenW cases } & \multicolumn{5}{|c|}{ MenW incidence } & \multirow{2}{*}{ AAPC } & \multirow{2}{*}{$\mathrm{p}$ value } \\
\hline & 2013 & 2014 & 2015 & 2016 & 2017 & 2013 & 2014 & 2015 & 2016 & 2017 & 2013 & 2014 & 2015 & 2016 & 2017 & & \\
\hline England $^{a}$ & 726 & 628 & 797 & 804 & 704 & 76 & 117 & 201 & 224 & 195 & 0.14 & 0.22 & 0.37 & 0.41 & 0.35 & $23 \%$ & $<0.001$ \\
\hline Germanyb & 345 & 278 & 287 & 339 & 281 & 10 & 10 & 10 & 26 & 26 & 0.01 & 0.01 & 0.01 & 0.03 & 0.03 & $35 \%$ & $<0.001$ \\
\hline Spain & 262 & 146 & 210 & $250^{c}$ & $261^{c}$ & 6 & 6 & 6 & 21 & 28 & 0.01 & 0.01 & 0.01 & 0.05 & 0.06 & $62 \%$ & $<0.001$ \\
\hline Poland ${ }^{a}$ & 235 & 180 & 198 & 157 & 204 & 3 & 4 & 7 & 7 & 9 & $<0.01$ & 0.01 & 0.02 & 0.02 & 0.02 & $29 \%$ & 0.056 \\
\hline Italy & 172 & 165 & 189 & 228 & 175 & 5 & 8 & 7 & 13 & 9 & $<0.01$ & 0.01 & 0.01 & 0.02 & 0.01 & $17 \%$ & 0.165 \\
\hline Netherlands ${ }^{a}$ & 117 & 77 & 85 & 153 & 198 & 7 & 1 & 9 & 50 & 80 & 0.04 & $<0.01$ & 0.05 & 0.29 & 0.47 & $133 \%$ & $<0.001$ \\
\hline Sweden & 74 & 49 & 53 & 62 & 49 & 3 & 2 & 11 & 18 & 17 & 0.03 & 0.02 & 0.11 & 0.18 & 0.17 & $58 \%$ & $<0.001$ \\
\hline Greece $^{\mathrm{b}}$ & 68 & 66 & 57 & 53 & 42 & 2 & 2 & 0 & 1 & 1 & 0.02 & 0.02 & 0 & 0.01 & 0.01 & $-22 \%$ & 0.404 \\
\hline Portugal & 61 & 54 & 66 & 40 & 44 & 1 & 0 & 0 & 1 & 2 & 0.01 & 0 & 0 & 0.01 & 0.02 & $50 \%$ & 0.300 \\
\hline $\begin{array}{l}\text { Czech } \\
\text { Republic }^{\mathrm{b}}\end{array}$ & 59 & 42 & 48 & 43 & 68 & 0 & 2 & 3 & 4 & 3 & 0 & 0.02 & 0.03 & 0.04 & 0.03 & $42 \%$ & 0.113 \\
\hline Switzerland & 50 & 37 & 43 & 51 & 53 & 3 & 6 & 13 & 15 & 18 & 0.04 & 0.07 & 0.16 & 0.18 & 0.21 & $44 \%$ & $<0.001$ \\
\hline Norway & 27 & 18 & 19 & 23 & 17 & 0 & 2 & 0 & 5 & 5 & 0 & 0.04 & 0 & 0.10 & 0.10 & $86 \%$ & 0.016 \\
\hline Finland $^{b}$ & 20 & 21 & 22 & 19 & 16 & 0 & 1 & 4 & 3 & 0 & 0 & 0.02 & 0.07 & 0.05 & 0 & $13 \%$ & 0.628 \\
\hline Total & 2,216 & 1,761 & 2,074 & 2,222 & 2,112 & 116 & 161 & 271 & 388 & 393 & 0.03 & 0.05 & 0.08 & 0.11 & 0.11 & $35 \%$ & $<0.001$ \\
\hline
\end{tabular}

AAPC: average annual percentage change; EMGM: European Meningococcal and Haemophilus Disease Society; IMD: invasive meningococcal disease; MenW: serogroup W Neisseria meningitidis.

a Based on laboratory-confirmed cases only.

${ }^{b}$ Reported numbers were based on a database merged from statutory notifications and laboratory surveillance.

c Extrapolated from the available laboratory surveillance data representing ca $80 \%$ of the notified cases, as notification data was not yet available.

proportion of MenW:CC11 in all IMD cases was found to be higher in adults than in infants [6].

In response to the rapid expansion of hypervirulent MenW:Cc11 in the UK, a MenACWY conjugate vaccination programme was introduced in August 2015 for all adolescents $13-18$ years of age, as well as university students up to 25 years of age [7]. In Italy, the programme was introduced for those 12-18 years of age in 2017 [8] and in the Netherlands for those 13-14 years of age in 2018, with a catch-up vaccination up to the age of $18[9,10]$. MenACWY vaccination has been recommended in Greece since 2011 for those 11-16 years of age [11] and in Austria since 2012 for those 10-13 year of age [12]. In contrast to earlier IMD epidemics where vaccines were not available or became available near the end of the epidemic, such as in New Zealand in the 1990s, several vaccines against MenACWY have been approved and are available in Europe [13,14].

The aim of the present study was to compile the most recent laboratory surveillance data on MenW IMD from several European countries to assess recent trends in Europe.

\section{Methods}

\section{Setting and data collection}

All national reference laboratories active in the European Meningococcal and Haemophilus Disease
Society (EMGM) were invited to a workshop on serogroup $W$ and $Y$ meningococci in Europe, taking place in November 2016. This workshop was organised using EMGM's institutional support from Pfizer, though the company did not have any influence on the outline or content of the meeting.

Reference laboratories from 14 countries were asked to participate in this study. The Czech Republic, England, Finland, Germany, Greece, Italy, the Netherlands, Norway, Poland, Portugal, Spain, Sweden and Switzerland provided the following data in an Excel spreadsheet: the number and age distribution of IMD cases (total and MenW), laboratory surveillance rate of the reported cases and data on Cc11 as a surrogate for the $W$ lineages from 2013-16. The participating countries represented over two thirds of the total combined European Union (EU)/European Free Trade Association (EFTA) population.

After identifying and correcting missing or inconsistent numbers, the dataset was compiled and analysed. IMD numbers were based on publicly available national reporting, which is mandatory in all 13 participating countries. On average, $90 \%$ of the reported IMD cases were laboratory confirmed by the national reference laboratories, ranging from 60-100\% depending on the country. To achieve a high quality standard on the serogrouping data, only MenW cases analysed by reference laboratories were included in the analysis, as 


\section{FIGURE 1}

Mean annual incidence of (A) invasive meningococcal disease (IMD) and (B) serogroup W N. meningitidis (MenW) IMD per 100,000 population and the proportion of (C) MenW IMD cases and (D) MenW clonal complex 11 IMD cases ${ }^{\mathrm{a}}$, by country, 13 EMGM-member countries, 2013-2017

A.

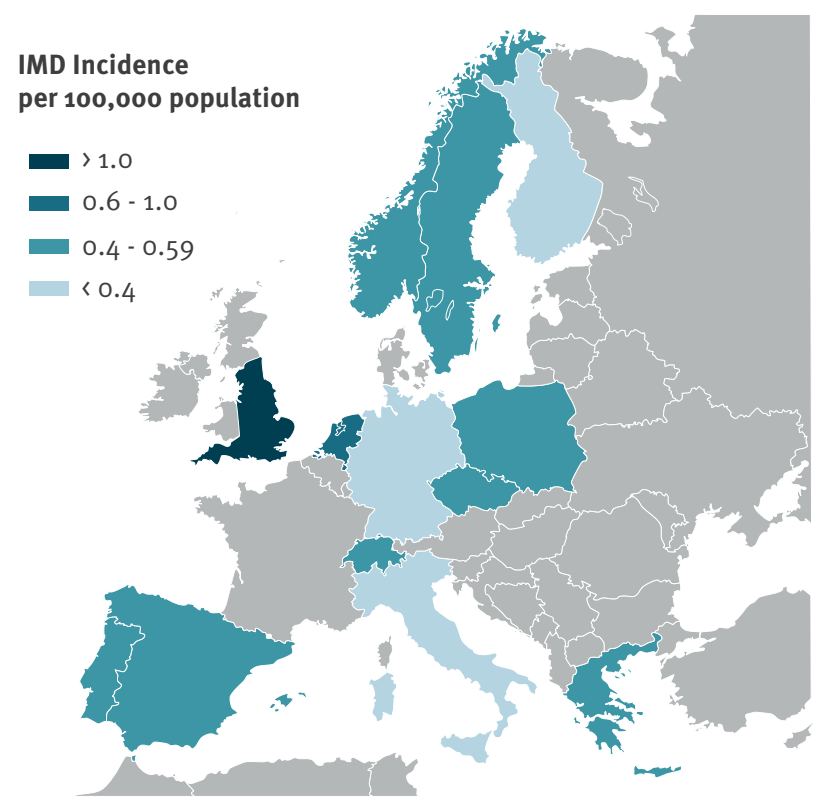

C.

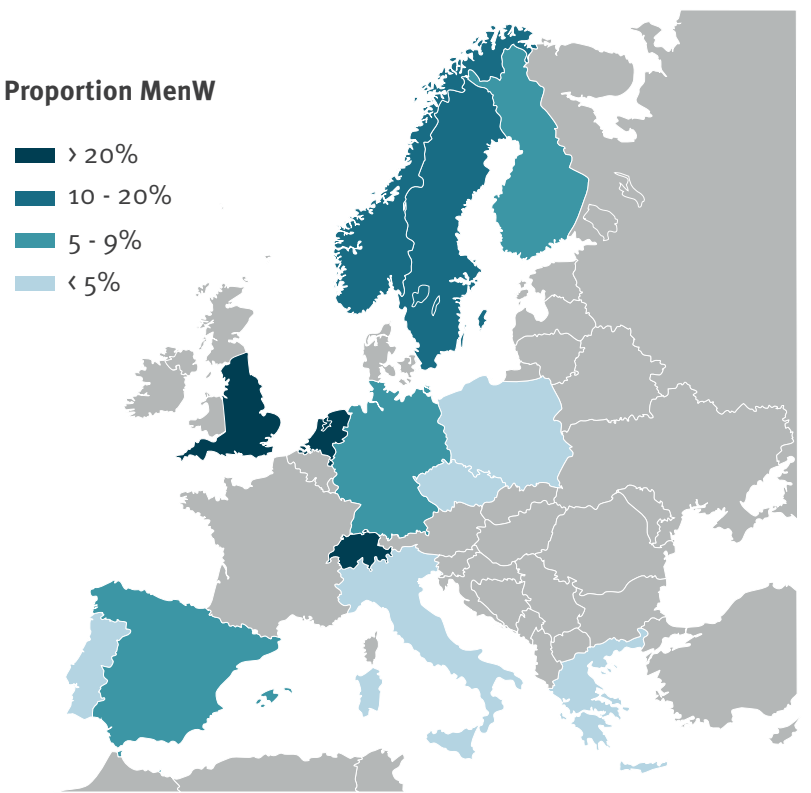

B.

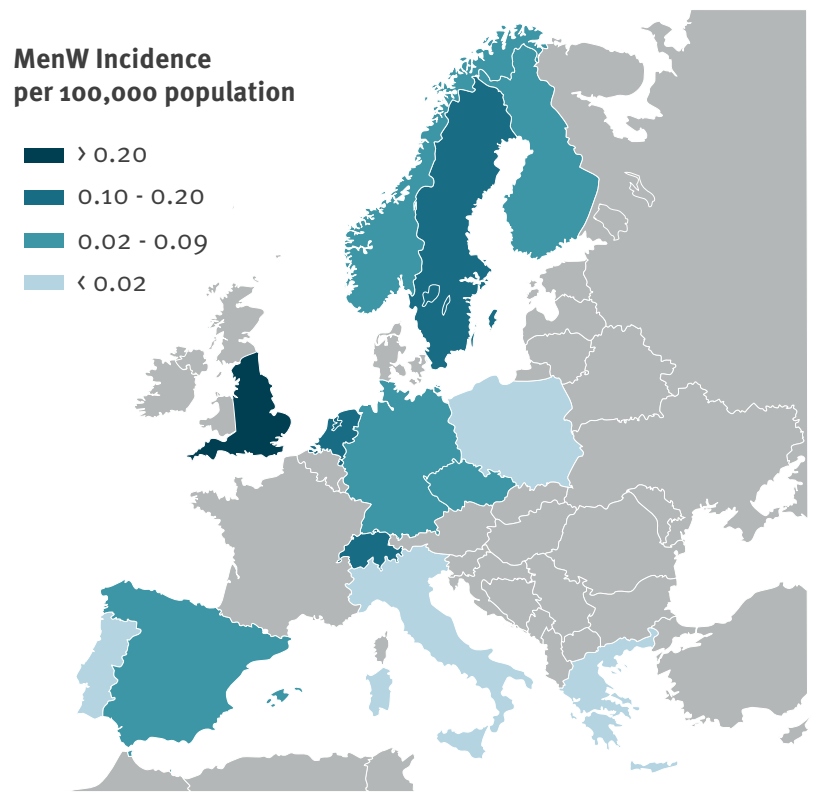

D.

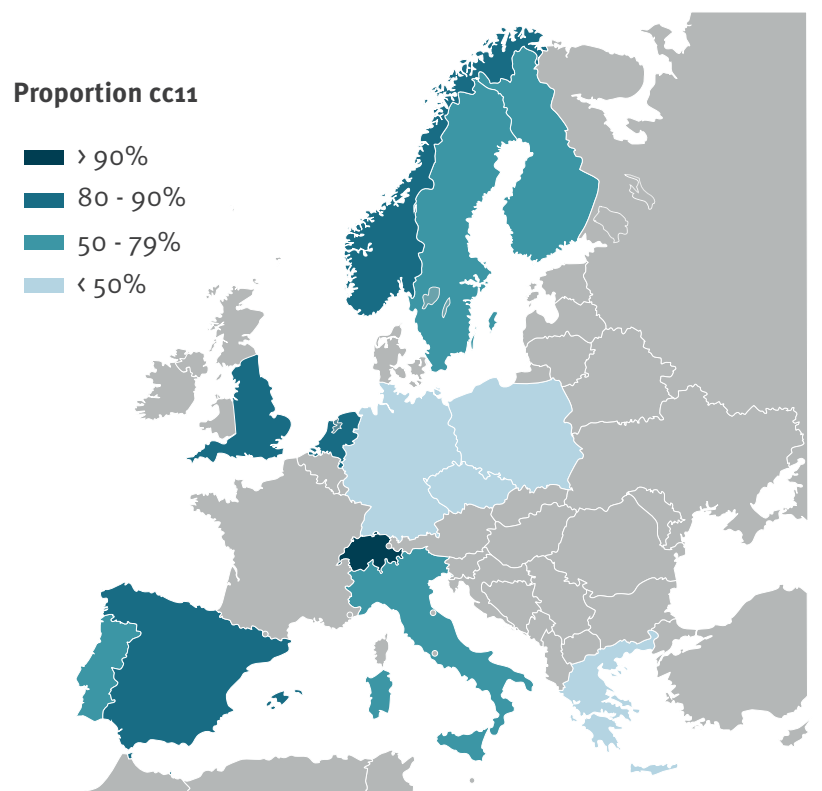

Cc11: clonal complex 11; EMGM: European Meningococcal and Haemophilus Disease Society; IMD: invasive meningococcal disease; MenW: serogroup W Neisseria meningitidis.

a 2013-16.

Map: Blank map of Europe cropped.svg by Leftcry / CC-BY-2.5. 
Incidence of invasive meningococcal disease due to serogroup W Neisseria meningitidis per 100,000 population, by year and country, 13 EMGM-member countries, 2013-2017 ( $\mathrm{n}=1,329)$

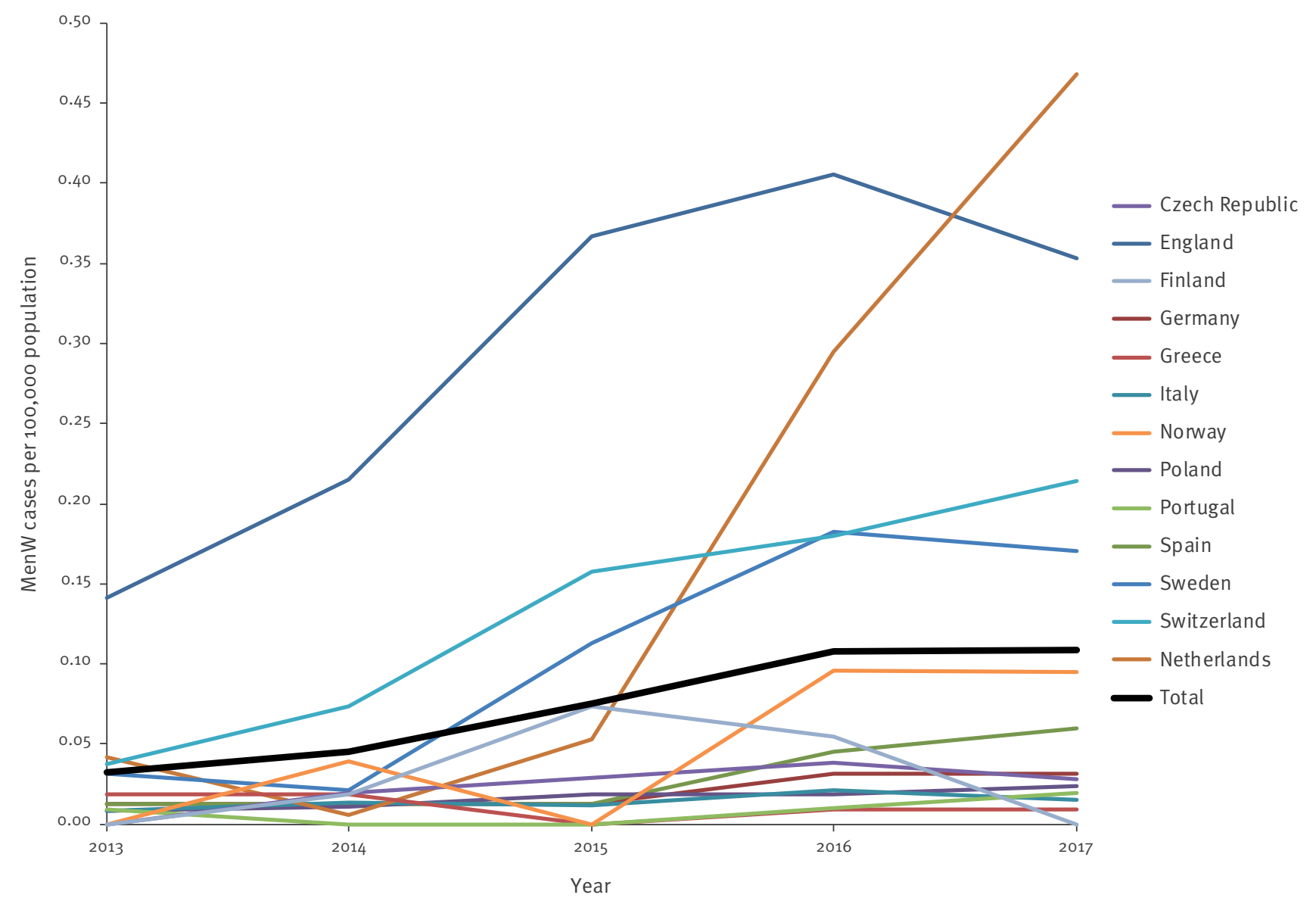

EMGM: European Meningococcal and Haemophilus Disease Society; MenW: serogroup W Neisseria meningitidis.

serogrouping in peripheral laboratories is not always performed by standardised methods. Reference laboratories reported the number of cases according to the laboratory criteria of the EU case definitions [15]. Typing data were matched at different levels with the statutory notification data. Preliminary 2017 data were collected on IMD and MenW cases, as at the time of writing sequence typing data was not yet available for many countries.

In England, national reporting is based on laboratoryconfirmed cases only; therefore, only such cases were included in this study [16]. Dutch and Polish data used in this study were also based on laboratory-confirmed cases. In the Czech Republic, Finland, Germany and Greece the reported numbers were based on mandatory notification data merged with laboratory surveillance data in a national database. As notification data were not available for the number of Spanish IMD cases in 2016-17, this number was extrapolated from the available laboratory surveillance data, representing approximately $80 \%$ of the notified cases in the years $2013-15$.
Population and age distribution data from 12 of the 13 countries were obtained from Eurostat [17]. Data on the English population were acquired from the UK Office for National Statistics [18]. As more recent data were not yet available, the English population number from 2016 was used for 2017.

\section{Typing}

The serogroup was determined by slide agglutination or PCR. Depending on the country, MLST-either on Sanger sequence or next generation sequencing datawas used to determine if strains belonged to cc11. The Bacterial Isolate Genome Sequence Database (BIGSdb) was used for data matching [19].

\section{Statistics}

Average annual percentage change in incidence was calculated for each country using Poisson regression. A $p$ value $<0.05$ was considered statistically significant. 
Percentage of serogroup W Neisseria meningitidis of all invasive meningococcal disease cases, 13 EMGM-member countries, 2013-2017

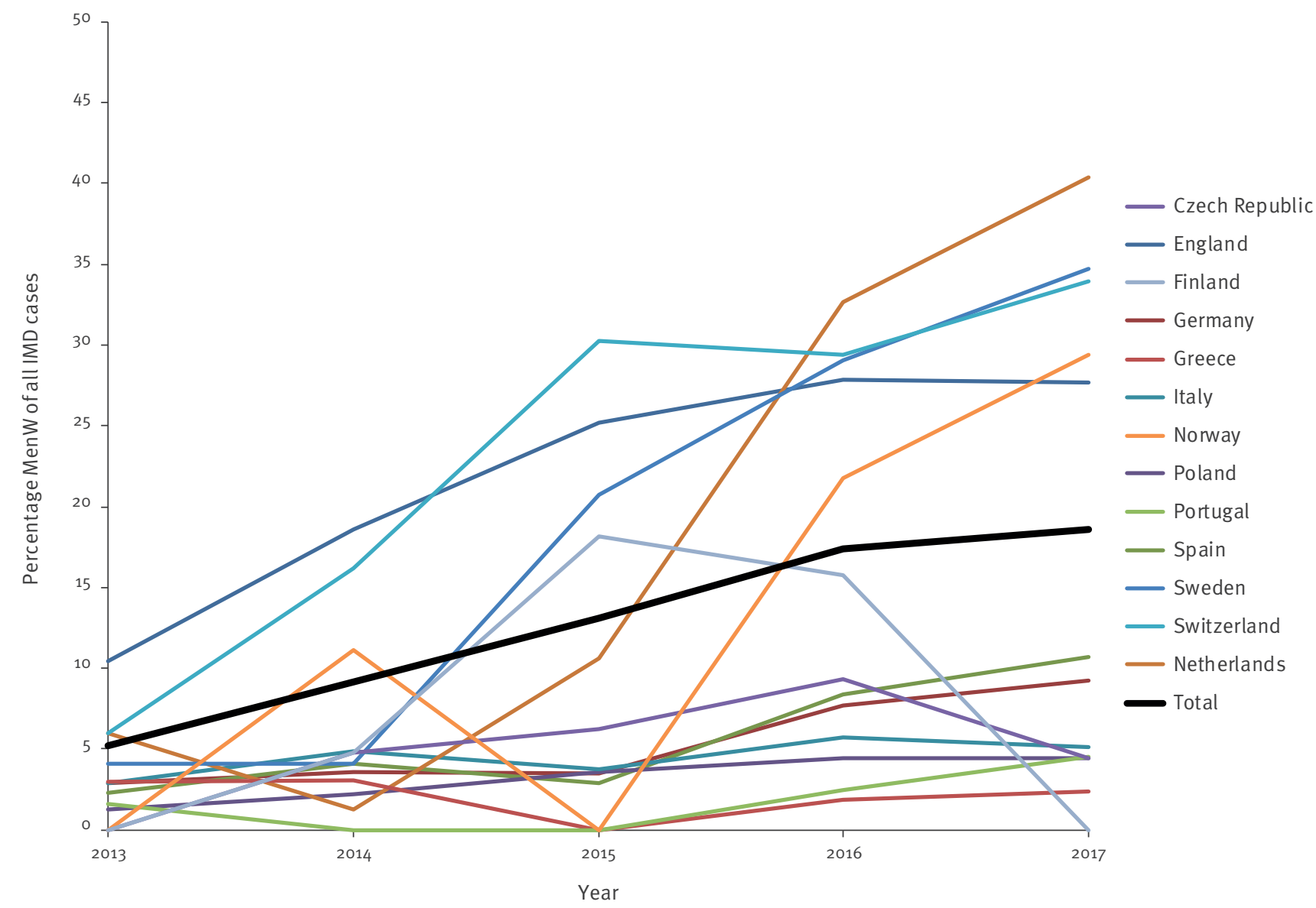

EMGM: European Meningococcal and Haemophilus Disease Society; IMD: invasive meningococcal disease; MenW: serogroup W Neisseria meningitidis.

\section{Results}

\section{Incidence of invasive meningococcal diseases cases}

From 2013-17, a total of 10,385 IMD cases were reported by the 13 participating countries. Accounting for the slightly growing population (2013: 355.7 million, 2014: 357.4 million, 2015: 358.5 million, 2016: 360.1 million, 2017: 360.8 million), this corresponds to an average annual incidence of 0.58 cases per 100,000 population. Serogroup W was responsible for 1,329 (13\%) of the total number of IMD cases (Table 1).

The average annual incidence of overall IMD and MenW IMD varied considerably between individual countries. For IMD, the incidence per 100,000 population ranged from 0.31 cases in Italy to 1.34 in England. For MenW IMD, the incidence per 100,000 population varied from 0.008 cases in Portugal to 0.17 cases in the Netherlands and 0.30 cases in England (Figure 1).
While the annual incidence of IMD remained stable in Europe from 2013-17 (2013: 0.62, 2014: 0.49, 2015: 0.58, 2016: 0.62, 2017: 0.59; average annual percentage change (AAPC): $1 \% ; p=0.214$ ), the incidence of MenW IMD (2013: 0.03, 2014: 0.05, 2015: 0.08, 2016: 0.11, 2017: 0.11; AAPC: $35 \%$; $p<0.001$ ) and the proportion of this serogroup among all IMD (2013: 5\%, 2014: 9\%, 2015: 13\%, 2016: 17\%, 2017: 19\%; $p=0.002$ ) increased significantly during this time. Significant increases in MenW incidence were observed in the Netherlands (AAPC: $133 \% ; p<0.001$ ), Norway (AAPC: $86 \% ; p=$ $0.016)$, Spain (AAPC: $62 \% ; p<0.001$ ), Sweden (AAPC: $58 \% ; p<0.001$ ), Switzerland (AAPC: 44\%; $p<0.001$ ), Germany (AAPC: $35 \%$; $p<0.001$ ) and England (AAPC: $23 \% ; p<0.001)$. The latter represents $61 \%$ of the total number of reported MenW cases in the 13 European countries during the overall study period. Though not statistically significant, there were also trends towards an increasing incidence in some other countries. (Table 1, Figure 2, Figure 3). 


\section{FIGURE 4}

Number and incidence per 100,000 population of invasive meningococcal disease (IMD) caused by serogroup W Neisseria meningitidis (MenW), by age group, and percentage of MenW of all IMD cases, 13 EMGM-member countries, 2016

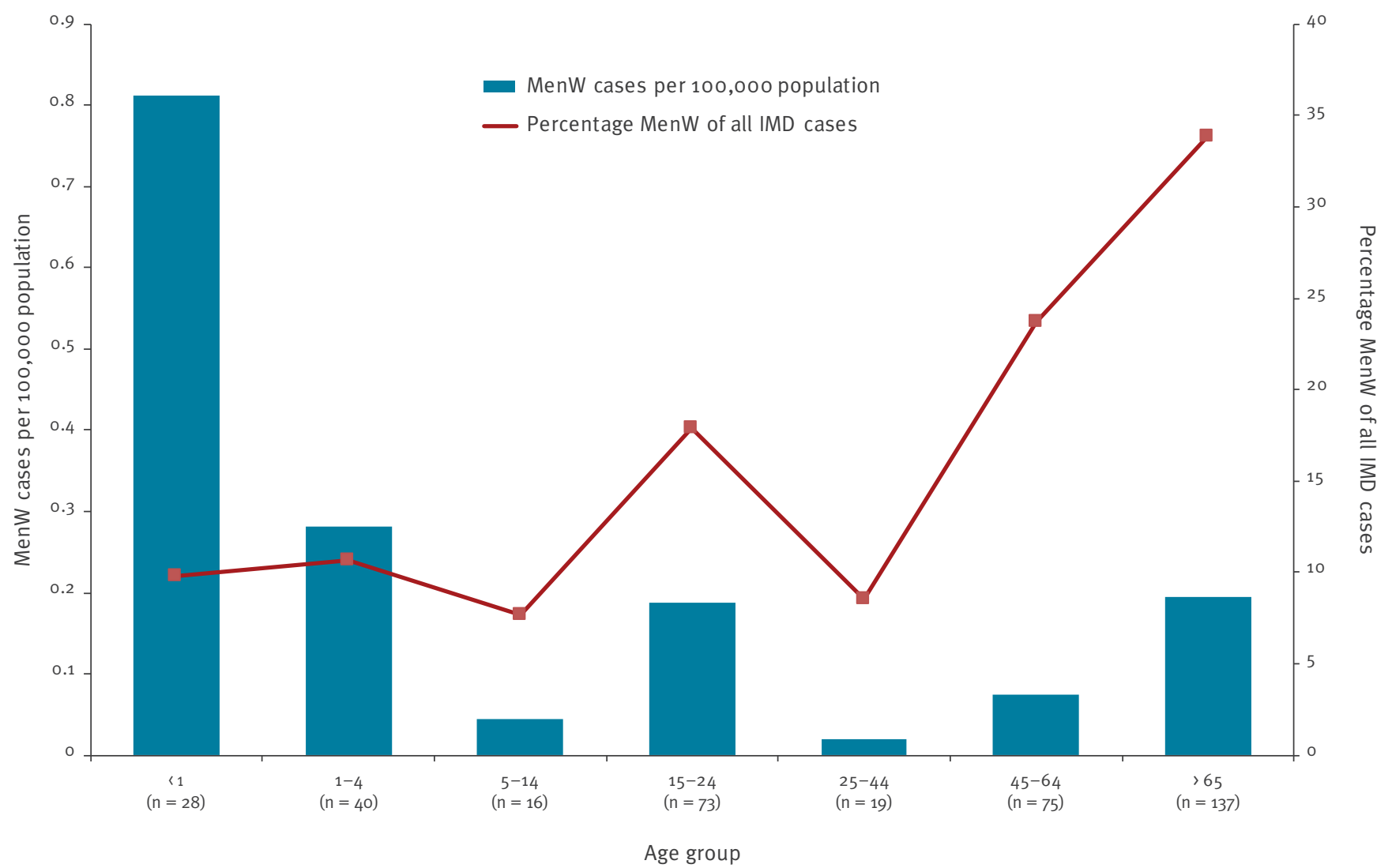

EMGM: European Meningococcal and Haemophilus Disease Society; IMD: invasive meningococcal disease; MenW: serogroup W Neisseria meningitidis.

The proportion of MenW among all IMD cases varied considerably between countries. The proportion of MenW was lowest in Portugal ( $2 \%, 4 / 265)$, Greece ( $2 \%$, $6 / 286)$ and Poland (3\%,30/974), while it was highest in Switzerland $(24 \%, 55 / 234)$, the Netherlands $(23 \%$, $147 / 630)$ and England (22\%, 813/3,659) (Figure 1).

\section{Age distribution}

In 2016, MenW IMD cases were overrepresented in the age groups $15-24$ years (18\% of all IMD cases, $73 / 408)$, $45-64$ years $(24 \%, 75 / 316)$ and $\geq 65$ years $(34 \%$, 137/405), while the percentage of MenW IMD cases in the vaccination target group of children $\leq 14$ years $(10 \%, 84 / 870)$, as well as those $25-44$ years of age ( $9 \%, 19 / 223)$, was lower than the average. However, the MenW IMD incidence was still highest in children $<5$ years of age (0.8/100,000 population). The lowest proportion of MenW IMD was observed in the age group 5-14 years $(8 \%, 16 / 209)$. In absolute numbers, most MenW IMD cases were registered in the age group $\geq 65$ years $(n=137)$. (Figure 4$)$

\section{Sequence typing}

Of the 936 reported cases of MenW IMD between 2013-16, $767(82 \%)$ strain isolates were analysed by MLST and 615 (80\%) belonged to cc11. The proportion of cc11 increased from $64 \%(64 / 100)$ in the year 2013 to $86 \%(265 / 307)$ in the year 2016 (Figure 5)

The proportion of sequence-typed MenW strains that belonged to cc11 varied considerably among countries, ranging from one in six in the Czech Republic to 31 in 34 in Switzerland (Figure 1).

\section{Discussion}

Laboratory surveillance and national health authority data from 13 European countries revealed an increase in MenW IMD in the period 2013-17. The MenW IMD incidence differed between participating countries and was highest in England and the Netherlands, as reported previously $[1,2]$. Significantly increasing incidences and proportions of MenW IMD among all IMD were observed in the majority of the participating 


\section{FIGURE 5}

Total serogroup W Neisseria meningitidis (MenW) invasive meningococcal disease (IMD) cases, cultured MenW sequence-typed cases and MenW:cc11 cases, 13 EMGM-member countries, 2016
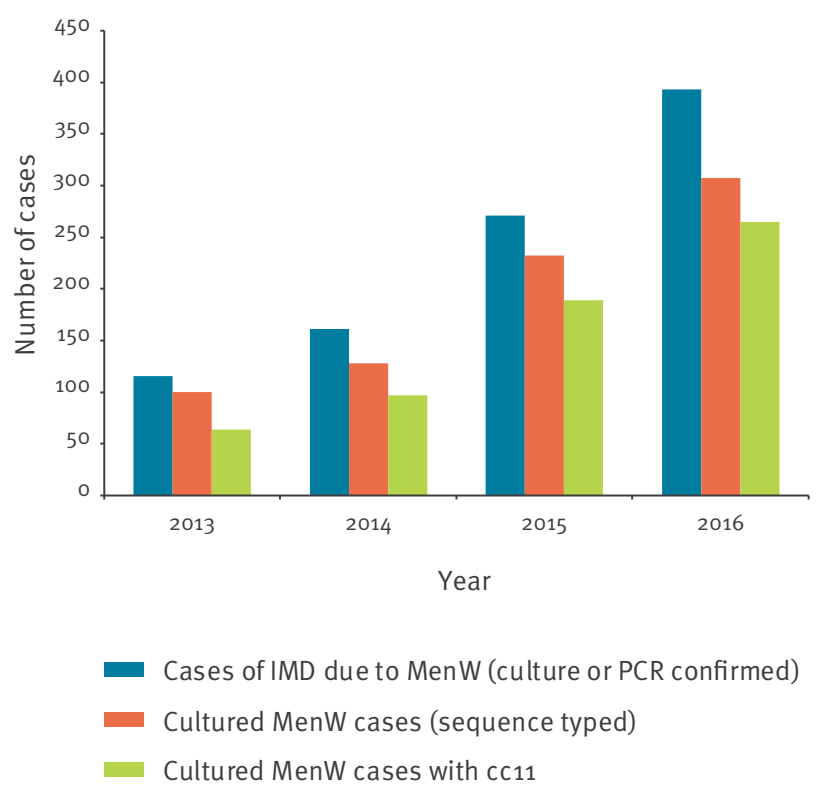

cc11: clonal complex 11; EMGM: European Meningococcal and Haemophilus Disease Society; IMD: invasive meningococcal disease; MenW: serogroup W Neisseria meningitidis.

countries, while the case numbers in other countries were too small to assess significance.

The increase seen in Europe follows a rising incidence of MenW in South America since 2004 [4]. More recently, a rising MenW incidence has been observed in Australia since 2013 [6] and in Canada since 2015 [20]. An epidemic spread of this MenW strain can be assumed for regions in the Americas, Australia and Europe. Notably, in 2015 an international outbreak related to the World Scout Jamboree in Japan was caused by the MenW:cc11 strain from the UK [21]. This was observed previously for other meningococci serogroups, including serogroup C:CC11 in the 1990 [22], serogroup A since the 1960 s [23] and serogroup B since the 1970s [24]. The dynamics of such intercontinental epidemic waves is hardly predictable and the mechanisms behind different dynamics of spread are still unclear. Typing by next generation sequencing revealed the relatedness of the MenW strains from South America, England [25] and the Netherlands [2]. It is possible that cc11 in general has a particular capacity to spread between countries, as these strains have shown this already in the past [21,26-28]. A possible experimental hypothesis is that cc11 strains are maintained in the population by frequent transmission events, despite a short duration of carriage [29].
It is noteworthy that the majority of cases of MenW IMD in Europe between 2013-16 occurred in those $\geq 45$ years of age, with the highest number of cases found in patients $\geq 65$ years of age. It is unclear whether this is the result of a circulation of strains in those $\geq 45$ years of age or if colonised children and teenagers are the major source of transmission to the older population. Indeed, carriage of meningococci is most frequent in adolescents and young adults, with a peak around the age of 20 that decreases with age; however, studies on carriage of meningococci in adults and the elderly are rare [30]. From the existing evidence, it may be suggested that despite infrequent disease, carriage in adolescents and young adults is much more abundant than in infants and toddlers [30]. Whether or not transmission occurs mainly within the affected age strata remains unclear. New carriage studies among all age groups are needed to inform about the MenW spread in Europe.

MenW is vaccine preventable and potent conjugate vaccines have been approved for use in Europe. Many European countries use meningococcal $C$ conjugate vaccines for infant immunisation. A general booster vaccination using a quadrivalent MenACWY vaccineas introduced in Greece [11], Austria [12], the UK [7], Italy [8] and the Netherlands [9,10]-boosters the waning MenC antibody titres [31] and provides immunity towards MenA, MenW and MenY.

As target groups and coverages vary in different countries (e.g. case numbers in some countries are low) and some programs were introduced quite recently, it is still too early to conclude on the effect of the vaccinations. In theory, by vaccinating adolescents, acquisition of carriage should be prevented and herd protection induced. This may be a cost-effective approach, as it might not be possible to immunise all groups. Public health decision-makers should be aware of the rise of MenW and, taking into account the situations in their respective countries, they may consider including quadrivalent meningococcal ACWY in their adolescent vaccination programmes.

The present study demonstrates the power of laboratory networks to provide surveillance data on short notice. The EMGM has already proved to be a functioning laboratory network on earlier occasions. The present survey relied on Sanger sequencing information, as next generation sequencing has not been rolled out to a sufficient extent in all countries. However, the example of the MenW spread shows that for particular questions this technique is indispensable. The causative agent is a particular derivative of the cc11, which can only be elucidated by high-resolution techniques [3]. The function of BIGSdb as a platform allowing the integration of genome sequence data was first validated using meningococcal sequence data as an example [19]. Future European-level meningococcal disease surveillance databases linking public health reporting data with high-resolution sequencing data would be 
beneficial for outbreak detection. The respective information technology is available; however, clarification of data protection issues and an unambiguous nomenclature is a prerequisite.

One limitation of this study is the incomplete coverage of Europe. Only 13 of the 32 EU/EFTA countries joined this project. However, more than two thirds of the population of the EU/EFTA area was addressed. It should be noted that in the UK, only England participated. Further, because of varying reporting and surveillance structures, the ways that data were obtained differed between countries, as did the laboratory surveillance coverage. Under-reporting may also have occurred on different levels, as cases of IMD could have been misdiagnosed or misclassified [32]. In addition, cases of MenW IMD may have been missed if they were not serogrouped by a national reference laboratory.

\section{Conclusion}

In conclusion, this study showed a concerning trend of increasing MenW incidence in several European countries, which needs to be followed carefully. Revision of vaccination schedules that takes into account an individual country's situation may be considered to counteract this trend. Furthermore, this study shows the strength of laboratory networks to combine and evaluate data on short notice. In the case of increasing MenW IMD, serogrouping and basic typing data were indispensable for the evaluation.

\section{Acknowledgements}

This publication made use of the PubMLST website (https://pubmlst.org/) developed by Keith Jolley (Jolley \& Maiden 2010, BMC Bioinformatics, 11:595) and the MRF Meningococcus Genome Library (https://www.meningitis. org/research-projects/mrf-meningococcus-genome-library). The development was funded by the Wellcome Trust.

\section{Conflict of interest}

Manuel Krone, Steve Gray, Raquel Abad, Georgina Tzanakaki, Paula Mölling, Maria João Simões, Pavla Křǐžová, Stéphane Emonet, Dominique A. Caugant, Izabela Waśko, Mirjam J. Knol, Susanne Jacobsson, Célia Rodrigues Bettencourt, Martin Musilek, Rita Born and Ulrich Vogel declare no conflict of interest.

Anna Skoczyńska: Assistance to attend scientific meetings and honoraria for lecturing funded from Baxter, GSK, Novartis and Pfizer; attendance in the Advisory Boards of GSK, Pfizer and Sanofi Pasteur; grants on behalf of the National Medicines Institute, Poland, from GSK, Novartis and Pfizer.

Paola Stefanelli declares research projects by Pfizer and GSK payed to the institution.

Arie van der Ende reports an Investigator Initiated Research Project (Study ID\# WI173197) by Pfizer payed to the Institution and consultancy activities for GSK and Pfizer payed to the Institution.
Maija Toropainen reports grants from GlaxoSmithKline and Pfizer to the National Institute for Health and Welfare for research projects in which she is a co-investigator.

Julio Vazquez acts as temporal advisor and receives grants for research from Sanofi-Pasteur, Novartis Vaccines, GlaxoSmithKline and Pfizer.

Ray Borrow performs contract research on behalf of Public Health England for GSK, Pfizer and Sanofi Pasteur.

\section{Authors' contributions}

Epidemiological investigations: Manuel Krone, Steve Gray, Raquel Abad, Anna Skoczyńska, Paola Stefanelli, Arie van der Ende, Georgina Tzanakaki, Paula Mölling, Maria João Simões, Pavla Kř́žová, Stéphane Emonet, Dominique A. Caugant, Maija Toropainen, Julio Vazquez, Izabela Waśko, Mirjam J. Knol, Susanne Jacobsson, Célia Rodrigues Bettencourt, Martin Musilek, Rita Born, Ulrich Vogel and Ray Borrow.

Laboratory investigations: Steve Gray, Raquel Abad, Anna Skoczyńska, Paola Stefanelli, Arie van der Ende, Georgina Tzanakaki, Paula Mölling, Maria João Simões, Pavla Křǐžová, Stéphane Emonet, Dominique A. Caugant, Maija Toropainen, Julio Vazquez, Izabela Waśko, Susanne Jacobsson, Célia Rodrigues Bettencourt, Martin Musilek, Ulrich Vogel and Ray Borrow.

Data Analysis: Manuel Krone, Ulrich Vogel and Ray Borrow.

Drafting the manuscript: Manuel Krone, Ulrich Vogel and Ray Borrow.

Writing the paper: Steve Gray, Raquel Abad, Anna Skoczyńska, Paola Stefanelli, Arie van der Ende, Georgina Tzanakaki, Paula Mölling, Maria João Simões, Pavla Křǐžová, Stéphane Emonet, Dominique A. Caugant, Maija Toropainen, Julio Vazquez, Izabela Waśko, Mirjam J. Knol, Susanne Jacobsson, Célia Rodrigues Bettencourt, Martin Musilek and Rita Born.

\section{References}

1. Ladhani SN, Beebeejaun K, Lucidarme J, Campbell H, Gray S, Kaczmarski E, et al. Increase in endemic Neisseria meningitidis capsular group W sequence type 11 complex associated with severe invasive disease in England and Wales. Clin Infect Dis. 2015;60(4):578-85. https://doi.org/10.1093/cid/ciu881 PMID: 25389259

2. Knol MJ, Hahné SJM, Lucidarme J, Campbell H, de Melker HE, Gray SJ, et al. Temporal associations between national outbreaks of meningococcal serogroup W and C disease in the Netherlands and England: an observational cohort study. Lancet Public Health. 2017;2(10):e473-82. https://doi. org/10.1016/S2468-2667(17)30157-3 PMID: 29253430

3. Eriksson L, Hedberg ST, Jacobsson S, Fredlund H, Mölling $\mathrm{P}$, Stenmark B. Whole genome sequencing of the emerging invasive Neisseria meningitidis serogroup W in Sweden. J Clin Microbiol. 2018;56(4):e01409-17. https://doi.org/10.1128/ JCM.01409-17 PMID: 29321195

4. Abad R, López EL, Debbag R, Vázquez JA. Serogroup $W$ meningococcal disease: global spread and current affect on the Southern Cone in Latin America. Epidemiol Infect. 2014;142(12):2461-70. https://doi.org/10.1017/ S0950268814001149 PMID: 24831052

5. Campbell H, Parikh SR, Borrow R, Kaczmarski E, Ramsay ME, Ladhani SN. Presentation with gastrointestinal symptoms and 
high case fatality associated with group W meningococcal disease (MenW) in teenagers, England, July 2015 to January 2016. Euro Surveill. 2016;21(12):30175. https://doi. org/10.2807/1560-7917.ES.2016.21.12.30175 PMID: 27035055

6. Martin NV, Ong KS, Howden BP, Lahra MM, Lambert SB, Beard $\mathrm{FH}$, et al. Rise in invasive serogroup W meningococcal disease in Australia 2013-2015. Commun Dis Intell Q Rep. 2016;40(4):E454-9. PMID: 28043219

7. Campbell H, Saliba V, Borrow R, Ramsay M, Ladhani SN. Targeted vaccination of teenagers following continued rapid endemic expansion of a single meningococcal group W clone (sequence type 11 clonal complex), United Kingdom 2015. Euro Surveill. 2015;20(28):21188. https://doi.org/10.2807/15607917.ES2015.20.28.21188 PMID: 26212140

8. Repubblica Italiana [Italian Republic]. Piano Nazionale Prevenzione Vaccinale. PNPV 2017-2019. Repubblica Italiana; 2017.Italian. Available from: http://www.salute.gov.it/ imgs/C_17_pubblicazioni_2571_allegato.pdf

9. Knol MJ, Ruijs WL, Antonise-Kamp L, de Melker HE, van der Ende A. Implementation of MenACWY vaccination because of ongoing increase in serogroup $\mathrm{W}$ invasive meningococcal disease, the Netherlands, 2018. Euro Surveill. 2018;23(16):26. https://doi.org/10.2807/1560-7917.ES.2018.23.16.18-00158 PMID: 29692317

10. Rijksoverheid [Government of the Netherlands]. Blokhuis kondigt grootschalige extra vaccinatie aan: Ruim half miljoen kinderen krijgen oproep. [Blokhuis announces large-scale extra vaccination: More than half a million children reveive a call]. The Hague: Rijksoverheid; 2018. Dutch. Available from: https://www.rijksoverheid.nl/actueel/nieuws/2018/07/17/ blokhuis-kondigt-grootschalige-extra-vaccinatie-aan-ruimhalf-miljoen-kinderen-krijgen-oproep

11. Tryfinopoulou K, Kesanopoulos K, Xirogianni A, Marmaras N, Papandreou A, Papaevangelou V, et al. Meningococcal Carriage in Military Recruits and University Students during the Pre MenB Vaccination Era in Greece (2014-2015). PLoS One. 2016;11(12):e0167404. https://doi.org/10.1371/journal. pone.0167404 PMID: 27907129

12. Nationales Impfgremium [National vaccination commitee]. Impfplan Österreich 2012. [Vaccination scheudule Austria 2012].German. Available from: http://www.doc-for-kids.at/ uploads/lexikon_pdf/impfplan_2012.pdf

13. Beresford NJ, Martino A, Feavers IM, Corbel MJ, Bai X, Borrow R, et al. Quality, immunogenicity and stability of meningococcal serogroup ACWY-CRM197, DT and TT glycoconjugate vaccines. Vaccine. 2017;35(28):3598 606. https://doi.org/10.1016/j.vaccine.2017.03.066 PMID: 28408122

14. Wong S, Lennon D, Jackson C, Stewart J, Reid S, Crengle $\mathrm{S}$, et al. New zealand epidemic strain meningococcal $B$ outer membrane vesicle vaccine in children aged 16-24 months. Pediatr Infect Dis J. 2007;26(4):345-50. https://doi. org/10.1097/01.inf.0000258697.05341.2C PMID: 17414400

15. The European Commission. Commission Regulation (EU) No 2018/945 of 22 June 2018 on the communicable diseases and related special health issues to be covered by epidemiological surveillance as well as relevant case definitions. Official Journal of the European Union. Luxembourg: Publications Office of the European Union. Available from: https://eur-lex. europa.eu/legal-content/EN/TXT/PDF/?uri=CELEX:32018Do94 $5 \&$ from $=\mathrm{EN}$

16. Ladhani SN, Waight PA, Ribeiro S, Ramsay ME. Invasive meningococcal disease in England: assessing disease burden through linkage of multiple national data sources. BMC Infect Dis. 2015;15(1):551. https://doi.org/10.1186/s12879-015-1247-7 PMID: 26626321

17. Eurostat. Population on 1 January by age and sex. Eurostat. [Accessed 22 Mar 2018]. Available from: http://appsso. eurostat.ec.europa.eu/nui/show.do?dataset=demo_pjan

18. Office for National Statistics (ONS). Population estimates for the UK, England and Wales, Scotland and Northern Ireland: mid-2016. London: ONS; 2017. Available from: https://www.ons.gov.uk/peoplepopulationandcommunity/ populationandmigration/populationestimates/bulletins/ annualmidyearpopulationestimates/mid2016

19. Jolley KA, Maiden MC. BIGSdb: Scalable analysis of bacterial genome variation at the population level. BMC Bioinformatics. 2010;11(1):595. https://doi.org/10.1186/1471-2105-11-595 PMID: 21143983

20. Tsang RSW, Ahmad T, Tyler S, Lefebvre B, Deeks SL, Gilca R, et al. Whole genome typing of the recently emerged Canadian serogroup W Neisseria meningitidis sequence type 11 clonal complex isolates associated with invasive meningococcal disease. Int J Infect Dis. 2018;69:55-62. https://doi. org/10.1016/j.ijid.2018.01.019 PMID: 29414677
21. Lucidarme J, Scott KJ, Ure R, Smith A, Lindsay D, Stenmark $B$, et al. An international invasive meningococcal disease outbreak due to a novel and rapidly expanding serogroup W strain, Scotland and Sweden, July to August 2015. Euro Surveill. 2016;21(45):30395. https://doi.org/10.2807/156o7917.ES.2016.21.45.30395 PMID: 27918265

22. Jelfs J, Munro R, Wedege E, Caugant DA. Sequence variation in the porA gene of a clone of Neisseria meningitidis during epidemic spread. Clin Diagn Lab Immunol. 2000;7(3):390-5. PMID: 10799451

23. Achtman M. Microevolution and epidemic spread of serogroup A Neisseria meningitidis--a review. Gene. 1997;192(1):13540. https://doi.org/10.1016/S0378-1119(97)00083-8 PMID: 9224883

24. Caugant DA, Frøholm LO, Bøvre K, Holten E, Frasch CE, Mocca LF, et al. Intercontinental spread of a genetically distinctive complex of clones of Neisseria meningitidis causing epidemic disease. Proc Natl Acad Sci USA. 1986;83(13):4927-31. https:// doi.org/10.1073/pnas.83.13.4927 PMID: 3088568

25. Lucidarme J, Hill DM, Bratcher HB, Gray SJ, du Plessis M, Tsang $\mathrm{RS}$, et al. Genomic resolution of an aggressive, widespread, diverse and expanding meningococcal serogroup $B, C$ and $W$ lineage. J Infect. 2015;71(5):544-52. https://doi.org/10.1016/j. jinf.2015.07.007 PMID: 26226598

26. Taha MK, Achtman M, Alonso JM, Greenwood B, Ramsay $M$, Fox A, et al. Serogroup W135 meningococcal disease in Hajj pilgrims. Lancet. 2000;356(9248):2159. https://doi. org/10.1016/S0140-6736(oo)03502-9 PMID: 11191548

27. Mölling $P$, Bäckman $A$, Olcén $P$, Fredlund H. Comparison of serogroup W-135 meningococci isolated in Sweden during a 23year period and those associated with a recent hajj pilgrimage. J Clin Microbiol. 2001;39(7):2695-9. https://doi.org/10.1128/ JCM.39-7.2695-2699.2001 PMID: 11427599

28. Elias J, Schouls LM, van de Pol I, Keijzers WC, Martin DR, Glennie A, et al. Vaccine preventability of meningococcal clone, Greater Aachen Region, Germany. Emerg Infect Dis. 2010;16(3):465-72. https://doi.org/10.3201/eid1603.091102 PMID: 20202422

29. Lappann M, Claus H, van Alen T, Harmsen M, Elias J, Molin S, et al. A dual role of extracellular DNA during biofilm formation of Neisseria meningitidis. Mol Microbiol. 2010;75(6):135571. https://doi.org/10.1111/j.1365-2958.2010.07054.x PMID: 20180907

30. Christensen H, May M, Bowen L, Hickman M, Trotter CL. Meningococcal carriage by age: a systematic review and metaanalysis. Lancet Infect Dis. 2010;10(12):853-61. https://doi. org/10.1016/S1473-3099(10)70251-6 PMID: 21075057

31. de Whalley PC, Snape MD, Kelly DF, Banner C, Lewis S, Diggle $L$, et al. Persistence of serum bactericidal antibody one year after a booster dose of either a glycoconjugate or a plain polysaccharide vaccine against serogroup C Neisseria meningitidis given to adolescents previously immunized with a glycoconjugate vaccine. Pediatr Infect Dis J. 2011;30(11):e2038. https://doi.org/10.1097/INF.obo13e318224fb14 PMID: 21673612

32. Gibbons CL, Mangen MJ, Plass D, Havelaar AH, Brooke RJ, Kramarz P, et al. Measuring underreporting and underascertainment in infectious disease datasets: a comparison of methods. BMC Public Health, 2014:14(1):147. https://doi. org/10.1186/1471-2458-14-147 PMID: 24517715

\section{License, supplementary material and copyright}

This is an open-access article distributed under the terms of the Creative Commons Attribution (CC BY 4.0) Licence. You may share and adapt the material, but must give appropriate credit to the source, provide a link to the licence and indicate if changes were made.

Any supplementary material referenced in the article can be found in the online version.

This article is copyright of the authors or their affiliated institutions, 2019. 